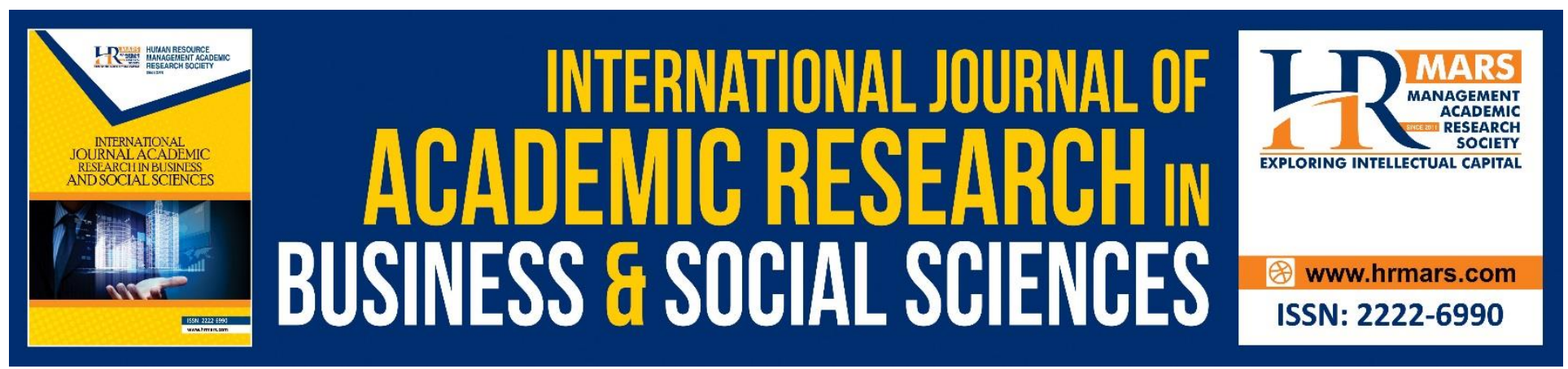

\title{
Cyberbully: Why Me?
}

\section{Nurul Farhana Saharrudin, Akmar Hayati Ahmad Ghazali}

To Link this Article: http://dx.doi.org/10.6007/IJARBSS/v10-i15/8233

DOI:10.6007/IJARBSS/v10-i15/8233

Received: 06 October 2020, Revised: 29 October 2020, Accepted: 22 November 2020

Published Online: 15 December 2020

In-Text Citation: (Saharrudin \& Ghazali, 2020)

To Cite this Article: Saharrudin, N. F., \& Ghazali, A. H. A. (2020). Cyberbully: Why Me? International Journal of Academic Research in Business and Social Sciences, 10(15), 58-66.

Copyright: () 2020 The Author(s)

Published by Human Resource Management Academic Research Society (www.hrmars.com)

This article is published under the Creative Commons Attribution (CC BY 4.0) license. Anyone may reproduce, distribute, translate and create derivative works of this article (for both commercial and non-commercial purposes), subject to full attribution to the original publication and authors. The full terms of this license may be seen

at: $\underline{\text { http://creativecommons.org/licences/by/4.0/legalcode }}$

Special Issue: Youth and Community Wellbeing: Issues, Challenges and Opportunities for Empowerment V1, 2020, Pg. 58 - 66 http://hrmars.com/index.php/pages/detail/IJARBSS JOURNAL HOMEPAGE

Full Terms \& Conditions of access and use can be found at http://hrmars.com/index.php/pages/detail/publication-ethics 


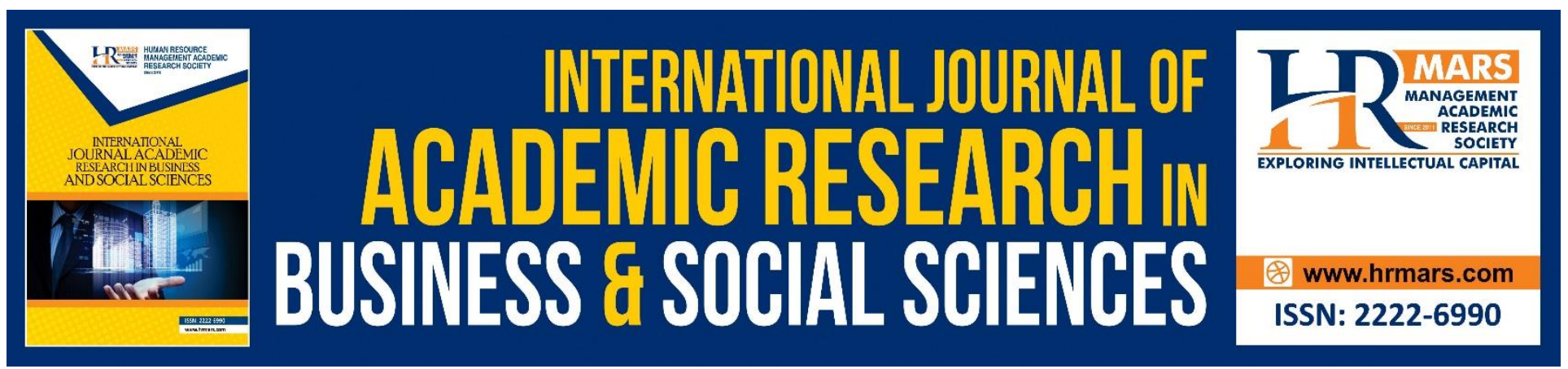

\title{
Cyberbully: Why Me?
}

\author{
Nurul Farhana Saharrudin \\ Institute for Social Science Studies, Universiti Putra Malaysia, 43300 Serdang, Selangor, Malaysia \\ Email: farhanasaharuddin@gmail.com
}

\author{
Akmar Hayati Ahmad Ghazali \\ Institute for Social Science Studies \\ Faculty of Modern Languages and Communication, Universiti Putra Malaysia, 43300 Serdang, \\ Selangor, Malaysia \\ Email: akmar@upm.edu.my
}

\begin{abstract}
Cyberbullying is a serious youths issue in Malaysia where with regard to highest cyberbullying prevalence among youths, Malaysia is ranked at number $17^{\text {th }}$. Therefore, the aim of this this study is to identify youth's engagement in cyberbullying activities. Using a quantitative approach, a total of 400 youths in Selangor, Malaysia were selected to be the respondents of this study by using a multistage cluster sampling. The results show that the most frequent cyberbullying activities action was to block individuals in instant messaging applications. Meanwhile, blocking others in an instant messaging application was a frequent form of cyberbully committed by Selangor youths. Cyberbullying is an emerging issue which would post negative implications if not taken seriously by all parties. All related parties inclusive of parents, teachers, educators and all members of virtual communities should create a positive environment that is able to prevent cyberbullying activities. Parental monitoring was highlighted and hopes it can be implying to reduce cyberbullying cases among youths.
\end{abstract}

Keywords: Cyberbullying, Cyber Education, Youths, Youths Development, Social Problem

\section{Introduction}

Information technologies are part and parcel of everyday life for youths. Being able to text or chat and post on social media has shaped the way in which youths communicate and interact with others. It cannot be denied that the growth of communication technologies has brought many advantages to youths, such as access to information and resources, knowledge sharing and learning networks, development and maintaining friendship. However, it also makes everyone exposed to several community dilemmas and youths are identified to be one of the most- affected groups. As Cankaya 
(2010); Eski (2012), and Tpocu, et.al (2010) said, youths are highly disclosed to cyberbullying due to the growth of the internet and communication tools.

Cyberbullying takes place over digital devices such as smartphones, computer, email and social media. According to Brady (2010), cyberbullies will threat against person by word or an expression wired. Usually, they will purposely send notes or text in hopes of distressing their prey. The presence of social media has increased the risks of cyberbullying. This medium attracts youth and exposes them to the risks of cyberbullying at a young age. Li (2006), added that the changes in technology have encouraged a trend of negative attitudes and ultimately spark to several social problems such as cyberbullying.

Cyberbullying is a multidimensional and a complex phenomenon that consists of frequent and persistent actions of tormenting, threatening, harassing, or embarrassing others by sending or posting unwanted messages or texts; threatening offensive or embarrassing messages, images, text or comments through social media messaging, emails or social networking sites (Görzig, \& Frumkin, 2013). Cyberbullying has often been operationalized as intentional, persistent and continuous actions involving imbalance of power between target and offender (Lee, Abell \& Holmess, 2015). Therefore, the impact of cyberbullying depends on many factors, and the most commonly cited in the literature are personal experience; previous bullying and/or engagement in cyberbullying (Cassidy, Faucher \& Jackson, 2013).

Cyberbullying is a serious youths issue in Malaysia. Ipsos Survey (2018) reported that nearly half of Malaysian parents know a child in their community who has experienced cyberbullying. In fact, cyberbullying is the virtual bullying that has no boundary to the physical. The difficulty in identifying the identity of the bullies has prompted youths to become involved in cyberbullying. Cyberbullying activities must be prevented as the impacts from such actions are severe. Bauman (2012) for example, said that typically victims will experience pressure and anxiety, which can later affect their academic performances. Most of the victims usually lose their focus (Goddard, 2008), while ErdurBaker \& Tanrikulu (2010) concluded that cyberbully causes hostile reactions among the victims. Despite the issue that have arisen, not much understood about cyberbullying among youths in Malaysia. Although studies across the globe have been actively done, a similar scenario cannot be seen within the Malaysia setting. The current study aims to find out the types of cyberbullying activities involved; and to identify factors that linked with cyberbullying behaviour.

\section{Types of Cyberbully Activities}

According to Blanchard (2012), there are several types of cyberbullying, such as the dating violence, abuse and distribution of text messages that interfere with personal information on social media sites. A study done by Che Noh and Ibrahim (2015), focused on cyberbullying among university students. A survey was done among 134 university students in the East Coast region of Peninsular Malaysia. They concluded that cyberbullying among university students occurred at a moderate level; some of the respondents were involved in contributing negative comments, disseminating personal pictures without permission, uploading videos without permission, slandering via social networks and online harassment.

Asanan, Hussain, Laidey (2017), shared that a few types of cyberbully activities among youths are posting mean and hurtful pictures of others, hurtful comments, spreading rumours about others and hacking into someone else's account. Ghazali et al., (2017), the informants get themselves 
involved in cyberbullying for revenge, just for fun and loneliness. Syahida et al., (2018), they identify the categories of cyberbullying, including harassment, flaming, outing, masquerading, dissing, catfishing, and slandering. Yehuda (2019), instant messaging (IM) was found to be the most common means of cyberbullying among the students. Jun (2020), said that the first most common type of cyberbullying is verbal violence followed by instant messaging.

The above discussion clearly shows that cyberbullies are not subject to just one type of activity. Perpetrators will do various things only to embarrass the prey. The state of depressed and embarrassed prey is like a trophy of victory for the bully. Therefore, this cyberbully problem must be handled as well as possible because it causes a lot of negative impacts on the victims and the bullies themselves.

\section{Factors that linked with Cyberbullying Behaviour}

There are various factors examined, but among the prominent ones are feeling of loneliness, selfesteem, empathy, and past experiences of being cyberbullied (EBC). However, these factors are less discussed in Malaysia. Balakrishnan (2015), explained that cyberbully victims with EBC might not have the courage to fight back their bullies physically, but this may not be the case in the virtual world as the nature of communication is different. Lee and Shin (2017) on the other hand have stated that cyberbully victims tend to bully others in the virtual world as they seek revenge and have redirected feelings.

According to Gayle and Jade (2015), people with lower self-esteem have been found to have a greater tendency to be involved in cyberbullying, both as the perpetrator and the victim. Handono et al. (2019), showed that there were significant relationships between cyberbullying behaviour and four determinant variables. The strongest was social support from friends followed by self-esteem, social support from family, attitude toward cyberbullying, and problematic Internet use.

It can be concluded that there are several factors that contribute to youth becoming bullies, such as lack of attention, loneliness, feelings of inferiority and used to be a victim of bullying. If we take a closer look, these factors are closely linked with psychology. Psychology problems that form are bound to affect their behaviour.

\section{Methods}

This study is quantitative in nature. A developed questionnaire consisting of 38 items was used as the main data collection instrument to measure youths' engagement in cyberbullying activities. Each of the item was measured by 5 Likert-scale ranging from 0 (never) to 4 (always) for answer. Before actual data collection begins, a pilot study was run to verify the instrument's reliability. The Cronbach alpha shows value of .888 and acquires the recommended value of .650 by Chua (2011), hence the instrument was reliable.

The total population of Malaysia in 2020 was around 32.7 million. In Selangor, only 2,828,000 were identified as youths aged between 15 - 40 years old out of the 5,800,100 residents (based on the report of the Department of Statistic, 2020). Based on Raosoft Sampling Calculator Software, an appropriate number of sampling for the study's population is 385 . The study however collected 400 respondents. Multi-stage cluster sampling was employed to select respondents. A total of 400 youths aged between 15 to 40 years old in Selangor was selected to be the sample of this study. The input 
was analysed using Statistical Package for Social Science (SPSS) whereby analyses such as frequency, percentage and mean score and correlation test were performed.

\section{Results}

Respondents' demographic background

There were 400 respondents in this study and the results of their demographic profiles are shown in Table 1 . The result revealed that the majority of respondents were female (50\%) and the remaining were male (49\%). The result indicates that most of the respondents involved falls under the age group of 20-22 (39.0\%).

This shows that youth are interested to be involved in this study because they are in the age group that is dependent on the internet. All information shared by them through this study are very useful and can be used as reference material by certain parties such as the Ministry of Youth and Sports and the Malaysian Communication and Multimedia Commission. This is important in ensuring that the authorities know the true needs of youth. All the more, the majority of respondents in this study are women who have potential to become victims of cyberbullying. Perhaps the authorities can devise proactive steps to address this problem.

Table 1: Respondents' Demographic background ( $N=400)$

\begin{tabular}{lcc}
\hline Profile & Frequency & Percentage \\
\hline Gender & & \\
Male & 199 & 49.8 \\
Female & 201 & 50.2 \\
Age & & \\
19 years and below & & 35.5 \\
$20-22$ years & 142 & 39.0 \\
23 years and above & 156 & 25.5 \\
\end{tabular}

\section{Internet Usage}

The data in Table 2 presented nearly more than half the youth (54.7\%). Majority of them spend more than 13 hours and have subscribed to internet services. This proves that youth spend up to 13 hours per day to surf the internet. That long duration of time would surely leave a bad impression to adolescents such as health problems, eg; difficult to focus in lessons or in work. Youth should have a good time management skill so that they can divide the time between internet using and social activities because these activities are more effective in building and strengthening one's knowledge. 
Table 2: Patten of internet usage $(\mathrm{N}=400)$

\begin{tabular}{lcc}
\hline Factor & Frequency & Percentage \\
\hline & & \\
Experience in using the internet & 98 & 24.5 \\
3 years or less & 83 & 20.8 \\
4 to 5 years & 219 & 54.7 \\
6 years or more & & \\
Subscribed to any internet services? & 330 & 82.5 \\
Yes & 70 & 17.5 \\
No & & \\
Time spent on internet usage & & 20.0 \\
3 hours or less & 80 & 25.0 \\
$4-7$ hour & 100 & 26.8 \\
$8-12$ hour & 107 & 28.3 \\
13 hours or more & 113 & \\
\hline
\end{tabular}

\section{Types of Cyberbullying Activities among Youths}

The results show that blocking others in an instant messaging application $(M=1.33)$ was a frequent form of cyberbully committed by Selangor youths. Other cyberbullying activities commonly committed by youths was recorded by the following statements; 'Don't care about others' (M=0.96), 'Condemn and speaking slang while using instant messaging application' ( $M=0.91)$, and 'Intend to remove someone from an online group chat or instant messaging application' ( $M=0.88)$.

Meanwhile, findings indicate that these youths were less engaged in much tedious cyberbullying activities such as 'Cheating or make tricks to get other's data background and post it on the Web' $(M=0.30)$, 'Conducting sexual harassment to others by phone or internet' $(M=0.30)$, and 'Using a webcam image of another person without their permission' ( $M=0.30)$.

The result of this study shows that the easiest way for someone to bully other people is by blocking them on messaging application. This will have the victim to wonder why he or she is treated that way and will definitely put emotional stress on the victims.

\section{Factors that Linked with Cyberbullying Behaviour}

Table 3 demonstrates the relationship between the five predictors and cyberbullying. All five predictors were found to yield a significant relationship with cyberbullying. EBC recorded a positive and strong relationship with cyberbullying $(r=.736, p=.0001)$ while loneliness was recorded to have a positive and moderate relationship with cyberbullying $(r=.460, p=.0001)$. Self-esteem on the other hand, recorded a positive and weak relationship with cyberbullying $(r=.231, p=.0001)$ while empathy also recorded a similar magnitude and direction $(r=.286, p=.0001)$.

The results of this study prove that most of the bullies have been victims themselves at some point in their lives. They become the bully because they wanted to take revenge for what they had been through. This cycle will not stop because the victims will turn into a bully once they're older. All 
of this is because the victims are influenced by psychological factors. Parents should play their roles and pay attention if they noticed any sudden changes in their child. Parent's concern can helps to solve the issues faced by their child before it gets worse.

Table 3: Relationship test between predictors and cyberbullying

\begin{tabular}{lcc}
\hline Factors & $r$ & $p$ \\
\hline EBC & .736 & .0001 \\
Loneliness & .460 & .0001 \\
Self-esteem & .231 & .0001 \\
Empathy & .286 & .0001 \\
\hline
\end{tabular}

\section{Recommendations}

This research has suggested with various recommendations on how to overcome the cyberbullying problems. It relates to parental monitoring, cyber education, counselling, media awareness and campaign, and the roles of the internet provider.

\section{Parental Monitoring}

Education starts from home. Parents should play proactive roles in educating their children. Nowadays, youths are being disclosed to cyberbullying. Every parent should supervise and monitor their children's activities, teach them about the dos and don'ts in the virtual world, inform them on the causes and the impacts of cyberbullying to them and their colleagues. The most important thing is, if they find out that their child is being bullied, find a way to help and stop them from continuing to be a bully victim.

\section{Cyber Education}

Patchin and Hinduja (2010), have all agreed on the importance of cyber education to solve social issues such as cyberbullying. Education regarding the ethics of using information and communication technology, matters related to online security and safety, privacy violations, limiting and shielding in personal information sharing must be taught to youths in general.

\section{Counselling}

Counselling may provide support for people in learning how to protect them online (Carter, 2013). Among the things accentuated by Carter (2013) are developing a skill repertoire, debrief after exposure or perpetration to cyberbullying and regulate behaviours to satisfy needs. Ybarra (2014) on the other hand, argues the need of counselling for children and adolescence in being exposed to cyber bullies

\section{Media Awareness / Campaign}

The media offers both good and bad sides to young people progress. Despite an increase in the possibility of youth's engagement in cyberbullying activities, the media can be utilized to increased public awareness about the danger of cyberbullying. The media awareness campaign is a powerful platform which reminds people of the risks of cyberbullying. Online forums can be useful for 
educating youths about cyberbullying. Information relating to the causes of cyberbully, their impacts and dealings if they become a potential cyber victim must be actively disseminated.

\section{The Roles of Internet Service Providers}

Based on Carter (2013), internet service providers have their own role in adopting codes and policies of online safety to prevent youths from becoming cyber victims. Understandably, users have the ability to report inappropriate online activities by clicking on a specified social report tool, reporting abuse pages, harassment and violent threats policy button or by contacting the website operator.

\section{Conclusion}

Cyberbullying is an emerging issue which would post negative implications if they are not taken seriously by all parties. All parties concerned including parents, teachers, educators and all members of the virtual communities should create a positive environment that can prevent cyberbullying activities. Parenting awareness is important to ensure that their children are safe physically and virtuously. Efforts to reduce and prevent the occurrence of cyberbullying symptoms that endangered the health and well-being of today's youths are indeed important. Future research should focus on identifying the factors related to cyberbullying, which are important for the future positive development of youths.

\section{Acknowledgement}

The research team would like to thank the Ministry of Higher Education for providing Fundamental Research Grant (Project Number: 05-01-16-1870FR) for the study.

\section{References}

Balakrishnan, V. (2015). Cyberbullying among young adults in Malaysia: The roles of gender, age and Internet frequency. Computers in Human Behavior, 46, 149-157

Bauman, S. (2012). Cyberbullying. Encyclopedia of diversity in education. Thousand Oaks, CA:Sage Publication, Inc.

Blanchard, K. (2011). Cyberbullying causes intense stress for some. Retrieved on 5 January 2016, from: http://www.emaxhealth.com/1020/cyberbullying-causes-intense-stress-some

Brady, K. P. (2010). Cyberbullying. Encyclopedia of law and higher education. Thousand Oaks, CA:Sage publication, Inc.

Cankaya, I. T. (2010). Effect of cyber bullying on the distrust level of preservice teachers: Considering internet addiction as a mediating variable. Procedia Computer Science, 3: $1353-1360$.

Carter, M. A. (2013). Third party observers witnessing cyber bullying on social media sites. Procedia Social and Behavioral Science, 84: 1296-1309.

Cassidy, W., Faucher, C., \& Jackson, M. (2013). Cyberbullying among youth: A comprehensive review of current international research and its implications and application to policy and practice. School Psychology International. 34. 575-612. 10.1177/0143034313479697.

Che Noh, C. H., \& Ibrahim, M. Y. (2014). Kajian penerokaan buli siber dalam kalangan pelajar UMT. Procedia - Social and Behavioral Sciences, 134, 323-329.

Chua, Y. P. (2011). Kaedah dan statistik penyelidikan: Kuala Lumpur: McGraw Hill Education. 
Eski, F. (2012). Examination of narcisistic personality traits' predicting level of internet addiction and cyber bullying through path analysis. Educational Science: Theory and Practice: $2771-2776$.

Gayle, B., \& Jade. K. (2015). Cyberbullying, self-esteem, empathy and loneliness. Computers in Human Behavior. 48. 10.1016/j.chb.2015.01.073.

Ghazali, A. H. A., Abdullah, H., Omar, S. Z., Ahmad, A., Samah, A. A., Ramli, S. A., \& Shaffril, H. A. M. (2017). Malaysian youth perception on cyberbullying: The qualitative perspective. International Journal of Academic Research in Business and Social Sciences, 7(4), 87-98.

Görzig, A., \& Frumkin, L. A. (2013). Cyberbullying experiences on-the-go: When social media can become distressing. Cyber psychology: Journal of Psychosocial Research on Cyberspace 7

Goddard, C. (2008). Cyber world bullying. Education Digest, 7(3): 9.

Handono, G., S., Kasetchai, L., \& Sittichai, R. (2019). Factors related with cyberbullying among the youth of Jakarta, Indonesia. Children and Youth Services Review, 99: 235-239.

Ipsos. (2018). Malaysian and global views on cyberbullying. Access from https://www.ipsos.com/enmy/malaysian-and-global-views-cyberbullying

Jun. W. (2020). A study on the cause analysis of cyberbullying in Korean adolescents. Int J Environ Res Public Health, 17(13): 4648

Lee, J., Abell, N., \& Holmes, J.L. (2015). Validation of measures of cyberbullying perpetration and victimisation in emerging adulthood. Research on Social Work Practice, 27, 456-467.

Lee, C., \& Shin, N. (2017). Prevalence of cyberbullying and predictors of cyberbullying perpetration among Korean adolescents. Computers in Human Behavior, 68, 352-358

Li,. Q. (2006). Cyberbullying in schools: A research of gender differences. School Psychological International: $157-170$.

Baker, O., E., \& Tanrikulu, I. (2010). Psychological consequences of cyber bullying experiences among Turkish secondary school children. Procedia Social and Behavioral Sciences, 2: 2771 - 2776.

Patchin, S. H. (2010). Bullying, cyberbullying and suicide. International academy for suicide research: $206-221$.

Patchin, J. W., \& Hinduja, S. (2010). Cyberbullying and self-esteem. Journal of School Health, 80, 614-621.

Hassan, S., Yacob, M., I., Nguyen, T., \& Zambri, S. (2018). Social media influencer and cyberbullying: A lesson learned from preliminary findings. Paper presenting at Knowledge Management International Conference (KMICe) 2018, 25 -27 July 2018, Miri Sarawak, Malaysia

Ybarra, M. M. (2004). Online aggressor/targets, aggressors, and targets: A comparison of associated youth characteristic. Journal of Child Psychology and Psychiatry: 1308-1316.

Yehuda, P. (2019). Cyberbullying and its influence on academic, social, and emotional development of undergraduate students. Heliyon. 5. 10.1016/j.heliyon.2019.e01393. 